\title{
富山県永見市における古津波堆積物調査
}

\author{
立石 良 $^{1 *} \cdot$ 河村綾太 ${ }^{2}$

\section{In search of paleotsunami deposits in Himi city, Toyama prefecture}

\author{
Ryo Tateishi ${ }^{1 *}$ and Ayata Kawamura ${ }^{2}$
}

\begin{abstract}
Sedimentological study was carried out in order to clarify the paleotsunami history in the northern Hokuriku region. Facies analysis for short core samples collected from the lowland behind a beach ridge in Shimao, Himi city, Toyama prefecture determine that the lowland beds consist of sediments from a beach ridge, a marsh, a pond and a swamp, and identify six event deposits in these sediments. Two of these event deposits or wood fragments rich layers were found in the almost same depth below the ground level, setting these two event deposits as an event bed. The observed ${ }^{14} \mathrm{C}$ age below this event bed is $2,344-2,155$ cal BP. The mineralogical and sedimentological characteristics as well as spatial distribution of the observed event bed suggest that it may have been originated from a tsunami. However, the possibility of a river flooding event cannot be excluded, and therefore further study is needed to clarify the origin of it.
\end{abstract}

Key words: handy core sampler, Hokuriku region, strand plain, tsunami deposits

\section{研究背景・目的}

過去に発生した津波の履歴や規模を推定することは, 将 来発生する津波の予測に扔いて重要である。古津波履歴の 調査は古文書調査と堆積物調查により行われるが, これら の調査は東北地方や太平洋側に集中しており, 日本海側, 特に北陸地方北部に抢いては古津波履歴の解明が進んでい ない．富山県を対象とした古津波履歴に関する調查成果は これまで, 矢野·竹内（2014）や卜部ほか（2015）により報

受付 : 2020 年 3 月 30 日 受理 : 2020 年 9 月 20 日

1 富山大学学術研究部 都市デザイン学系

干930-8555 富山県富山市五福 3190

Faculty of Sustainable Design, Academic Assembly, University of Toyama, 3190 Gofuku, Toyama city, Toyama prefecture

2 富山大学理学部地球科学科

干930-8555 富山県富山市五福 3190

Department of Earth Sciences, University of Toyama, 3190

Gofuku, Toyama city, Toyama prefecture

* Corresponding author: ryo0821@gmail.com
告されているが，イベントの成因や発生年代について，未 た確定的なことは分かっていない，そこで本研究では，富 山県を含む北陸地方北部の古津波履歴を明らかにすること を目的として，富山県永叒市島尾地区において打ち込み式 サンプラーを用いた堆積物調查を行った.

\section{調查地域の概説}

\section{1. 地形・地質}

調査地域は能登半島の基部, 富山湾に面した富山県水見 市に発達する平野の南東部に位置する（Fig. 1A, Fig. 1B）。 この平野は, 海岸沿いに約 $9 \mathrm{~km}$ に渡って発達する浜堤列 と, その背後の低地帯からなる (Fig. 1B). 山崎ほか (1983) によれば, この低地带は, 完新世中期のいわゆる縄文海進 時の入り江〜湾が埋積されてできた低地である．さらに内 陸には, やや開析された海成段丘からなる丘陵地が広がる。

海成段丘は，新第三紀鮮新世から第四紀更新世初頭と推 定される水見層群と，これと不整合関係にある第四紀更新 


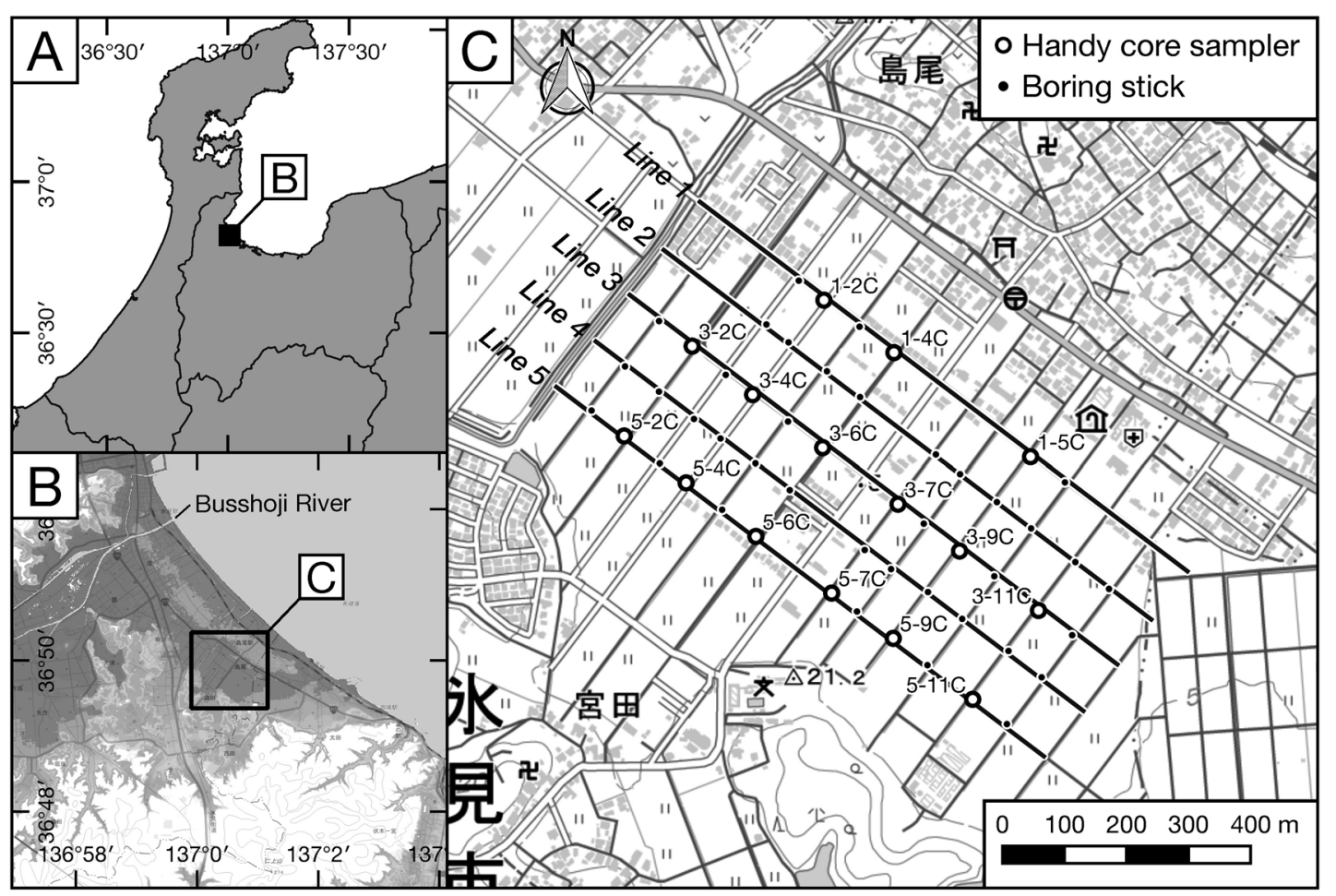

Fig. 1 Location map of the study area. A: Index map; B: Topography of the study area. Darker colors indicate a lower elevation. The topography was created from the $5 \mathrm{~m}$ mesh DEM, GSI (Geospatial Information Authority of Japan).; C: Detailed map of the study area. The base map is a GSI tile (pale map).

世の地層からなる．前者は, 下位より鮮新世の乑積層と薮 态層, および更新世前期初頭の十二町層に細分され，後者 は，更新世前期の埴生層，更新世中期の上㚙势層，および 更新世後期の乼層からなる。 そして, 低地には完新世の地 層が分布する（山崎ほか, 1983）。

調查地域は浜堤列と標高 $20 \mathrm{~m}$ 程度の丘陵地に挟まれた 浜堤背後の低地帯であり, 現在は水田として利用されてい る (Fig. 1C)，海岸線に直交する方向の浜堤列の幅は約 500 $\mathrm{m}$ で, 最大標高は $8 \mathrm{~m}$ である。低地带は海岸線から約 $1 \mathrm{~km}$ 離れており, 平均的な標高は約 $3.9 \mathrm{~m}$ である. 調查地域の 低地带の地下の情報は地盤ボーリングも含めて公開されて 扮らず, 本研究が初めての学術的調查である.

国土庁土地局（1998）が示した土地保全図（土地利用動 向図 I）によれば, 調查地域周辺で戋場整備事業の記録はな い. 米軍が 1953 年に撮影した空中写真（写真番号 USA-M 144-44〜50) でも，現在とほぼ変わらない様子が確認でき る.このように, 調查地域周辺では, 大規模な地形改変は なされていない.

\section{2. 津波履歴}

調査地域周辺に㧈ける歴史津波としては, 1741 年（寞保
元年）渡島大島の山体崩壊と 1833 年（天保 4 年）庄内沖地 震によるものが挙げられる. 1741 年の津波は, 現在の石川 県輪島市門前町で最大高さ3 4 m (羽鳥, 1984), 1833 年 の津波は, 同じく輪島市本町で高さ $5.3 \mathrm{~m}$, 水見市では高さ 1〜2m とされている(羽鳥，1990）.

調查地域周辺に扔ける有史以前の津波を対象とした調查 は2 例あり, 矢野・竹内 (2014) は, 富山県射水市放生津 潟の地盤ボーリング調査で採取された土質標本から底生有 孔虫の分析を実施し，津波堆積物の有無を検討した。 その 結果, 砂質粘土からなる試料より Ammonia ketienziensis が 検出され，この種の富山湾に扔ける分布水深がストームの 波浪限界水深より深いことから津波堆積物であるとした。 卜部ほか（2015）は，文部科学省による日本海地震津波調 査プロジェクトの一環として, 石川・富山地域でボーリン グ調查を実施した。本研究の調査地域周辺では, 旧十三 町潟地区の 4 地点で調査が行われ, 地層の堆積環境の推 定とイベント堆積物の有無の検討がなされた，それによる と, 旧十二町潟地区の地層の堆積環境は, 下位から砂質の 内湾, 砂質の潟湖, 磷混じりの砂州, 潟湖とされ, 砂質の潟 湖の堆積物から 3 層のイベント堆積物が認定されている. 
矢野 • 竹内 (2014), 卜部ほか (2015) のいずれも, イベン ト堆積物の年代に関する記載はされていない.

\section{調 查 手 法}

\section{1. 調查}

調査地域の低地帯において, 海岸線と平行な方向に 5 本, 直交する方向に 12 本の測線を設け，その交点で検土杖を
用いた堆積物の採取・観察と打ち込み式サンプラーを用い たコア採取を行った（Fig. 1C）。海岸線と平行な方向の測 線には，海側から 1〜5の番号を付与した．測線の間隔は 海岸線と平行な方向で約 $65 \mathrm{~m}$, 直交する方向で約 $80 \mathrm{~m}$ で あり, 調査地域は $800 \mathrm{~m}$ (北西-南東方向) $\times 400 \mathrm{~m}$ (北東-南 西方向）の長方形の範囲である.

検土杖調査は, 堆積物の概観を把握し, コア採取地点を 決定するため各測線の交点（計 52 地点）で実施し, 堆積物

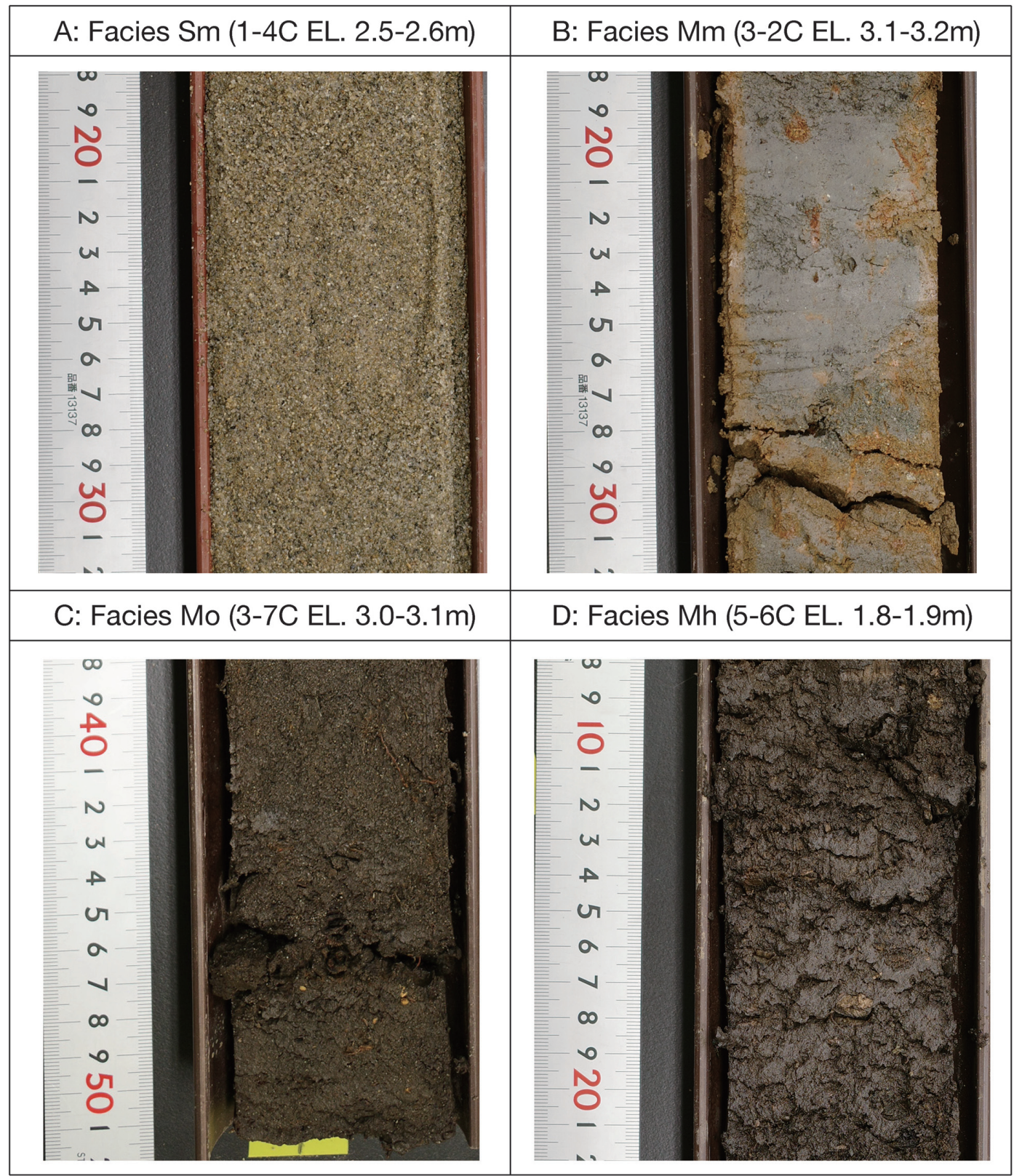

Fig. 2 An example of the sedimentary facies. A: Facies Sm, B: Facies Mm, C: Facies Mo, D: Facies Mh. 
の色, 粒度, 淘汰を記載した。検土杖の最大掘削深度は 1.5 $\mathrm{m}$, 内径は $1 \mathrm{~cm}$ である. 打ち込み式サンプラーによる調查 は, 調查地域の地層の堆積環境の推定, およびイベント堆 積物の抽出と対比を目的として, 検土杖調査を行った 52 地点の内, 測線 1 , 測線 3 , 測線 5 の合計 15 地点で行った (Fig. 1C). 打込み式サンプラーの最大掘削樑度は $2.5 \mathrm{~m}$, 内径は $60 \mathrm{~mm}$ である。採取したコアは室内に持ち込み，堆 積物の色, 粒度, 淘汰, 含有物などの詳細な観察と記載を 行った。また，イベント堆積物の年代を含めた地層の堆積 年代を把握するため, 有機物試料を採取して AMS 法によ る放射性炭素年代測定を行った。なお，放射性炭素年代測 定は, Beta Analytic 社に依頼した.

\section{2. 解析}

打ち込み式サンプラーを用いて採取したコア試料に対し て堆積相解析の方法を適用した．認定された堆積相の垂直 方向と水平方向の変化から, 調查地域の堆積環境の時空間 変化を復元した. 次いで, 地質学的に見て短期間で堆積し たと判断される堆積物をイベント堆積物として抽出した.

\section{結果}

\section{1. 堆積相解析}

\section{堆積相 Sm（浜堤の堆積物 ; Fig. 2A)}

記載：黄色〜黄土色を呈する非常に淘汰の良い塊状の細 粒砂〜中粒砂からなり，まれに植物片を含む。層厚は 17 $\mathrm{cm}$ 以上である. 最も海側の測線 1 全体と, 測線 3 の最下 部に分布し, 測線 5 では認められなかった（Figs. 3〜 5).

解釈：調查地域のすぐ海側には浜堤が分布することから, この砂層は浜堤の堆積物と解釈される。淘汰の良さは分級 作用を受けたことを示しており，風による運搬を支持する.

\section{堆積相 Mm（池や沼の堆積物； Fig. 2B）}

記載：灰色〜暗灰色を呈する淘汰の良い塊状の粘土から なり，まれに植物片を含む。植物片は黒色で，長軸の長さ が $5 \mathrm{~mm}$ 程度のものが多く，ほほ水平に産出する，層厚は $8 \mathrm{~cm} \sim 31 \mathrm{~cm}$ である. 測線 3, 測線 5 で堆積相 Mo や堆積相 $\mathrm{Mh}$ とともに, 堆積相 Sm の上位に分布する (Figs. 4 and 5). 堆積相 Mo や堆積相 Mh と比べて層厚が薄く, 分布範囲は 2 測線分（海岸線と平行な方向に約 $130 \mathrm{~m}$ ，直交する方向に 約 $160 \mathrm{~m} ）$ 未満である。この堆積相は，浅部に分布する傾 向がある.

解釈：水の流れがほとんどない場所で浮遊粒子が沈殿し たものであり，有機物にそしいことから，湖沼のような環 境で堆積したものと考えられる。分布範囲が狭いことか ら, 湖と呼べるほど大きな環境ではなかったと推定される ことから，この粘土層は池や沼の堆積物と解釈される.

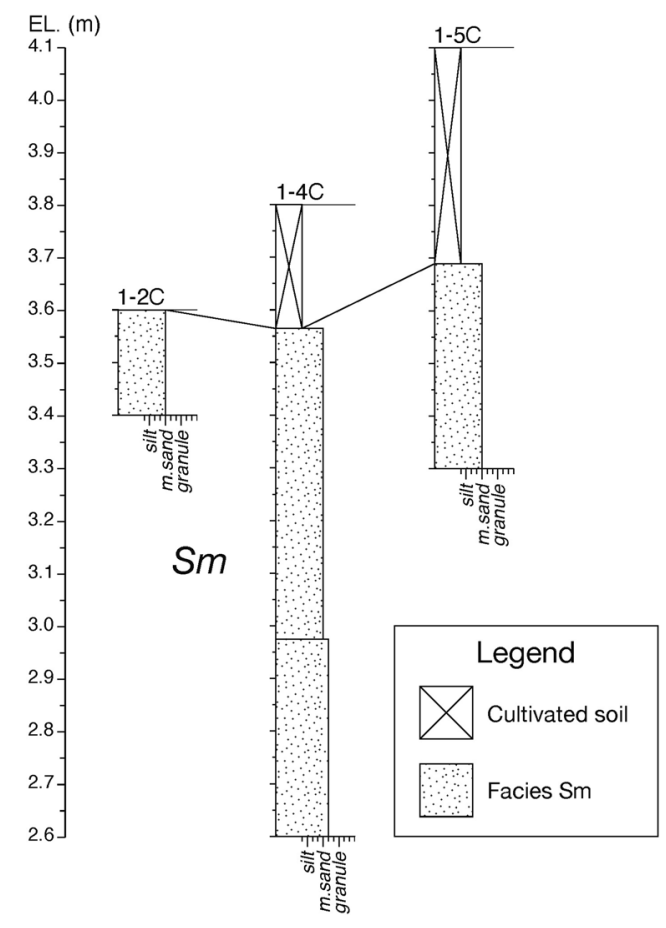

Fig. 3 Columnar sections of Line 1.

\section{堆積相 Mo（湿地の堆積物； Fig. 2C）}

記載：暗灰色を呈し, 有機物に富む塊状の粘土からなり, 植物片を含む．植物片は未分解で, 長軸の長さが $1 \mathrm{~cm}$ 程 度のものが多く，いずれもほぼ水平に産出する，層厚は 3 $\mathrm{cm} \sim 83 \mathrm{~cm}$ である. 測線 3, 測線 5 で堆積相 $\mathrm{Mm}$ や堆積相 $\mathrm{Mh}$ とともに, 堆積相 $\mathrm{Sm}$ の上位に分布する (Figs. 4 and 5). 測線 3 では海岸線と平行な方向に 5 測線分（約 $325 \mathrm{~m}$ ) 連 続して分布するが，測線 5 では連続して分布することはな い.

解釈：堆積相 $\mathrm{Mm}$ と同様，水の流れがほとんどない場所 で堆積したものと考えられる。堆積相 $\mathrm{Mm}$ より有機物を 多く含むことから，この粘土層は湿地の堆積物と解釈され る. 堆積相 Mh とは異なり, 砕屑粒子を含むことから, 浮 遊粒子が運搬される程度の流れはあったものと思われる。

\section{堆積相 Mh（湿地の堆積物； Fig. 2D）}

記載：暗褐色を呈し，分解が進んだ瀻維状の腐植と未分 解の植物片からなる．植物片は，長軸の長さ $1 \mathrm{~cm} \sim 2 \mathrm{~cm}$ 程 度の葉や枝の破片が最も多く見られるが，見かけの直径 50 $\mathrm{cm}$ ほどの幹が含まれる場合もある。植物片はいずれもほ ぼ水平に産出し, 一部の層準で濃集する様子が見られた。 層厚は $5 \mathrm{~cm} \sim 176 \mathrm{~cm}$ である. 測線 3, 測線 5 で堆積相 $\mathrm{Mm}$ や堆積相 Mo とともに堆積相 Sm の上位に分布する (Figs. 4 and 5). 測線 5 では海岸線と平行な方向に 6 測線分（約 




Fig. 4 Columnar sections of Line 2. A E: The event deposits. HMS3-2_01 and HMS3-2_02: The radiocarbon dating samples.

$390 \mathrm{~m} ＼mathrm{~ 連 続 し て 分 布 す る か ゙, ~ 測 線 ~} 3$ では 3 測線以上連続す ることはない。 この堆積相は, 地下の深い部分に分布する 傾向がある.

解釈 : 草本や木本の遺骸が集積して形成されたものであ ることから, この腐植は湿地の堆積物と解釈される。砕屑 粒子をほとんど含まないことから, 植生の影響で流れが淀 んだ環境だったと推定される。

\section{2. 堆積環境の変遷}

浜堤の堆積物と解釈される堆積相 $\mathrm{Sm}$ の上面は, 海側か

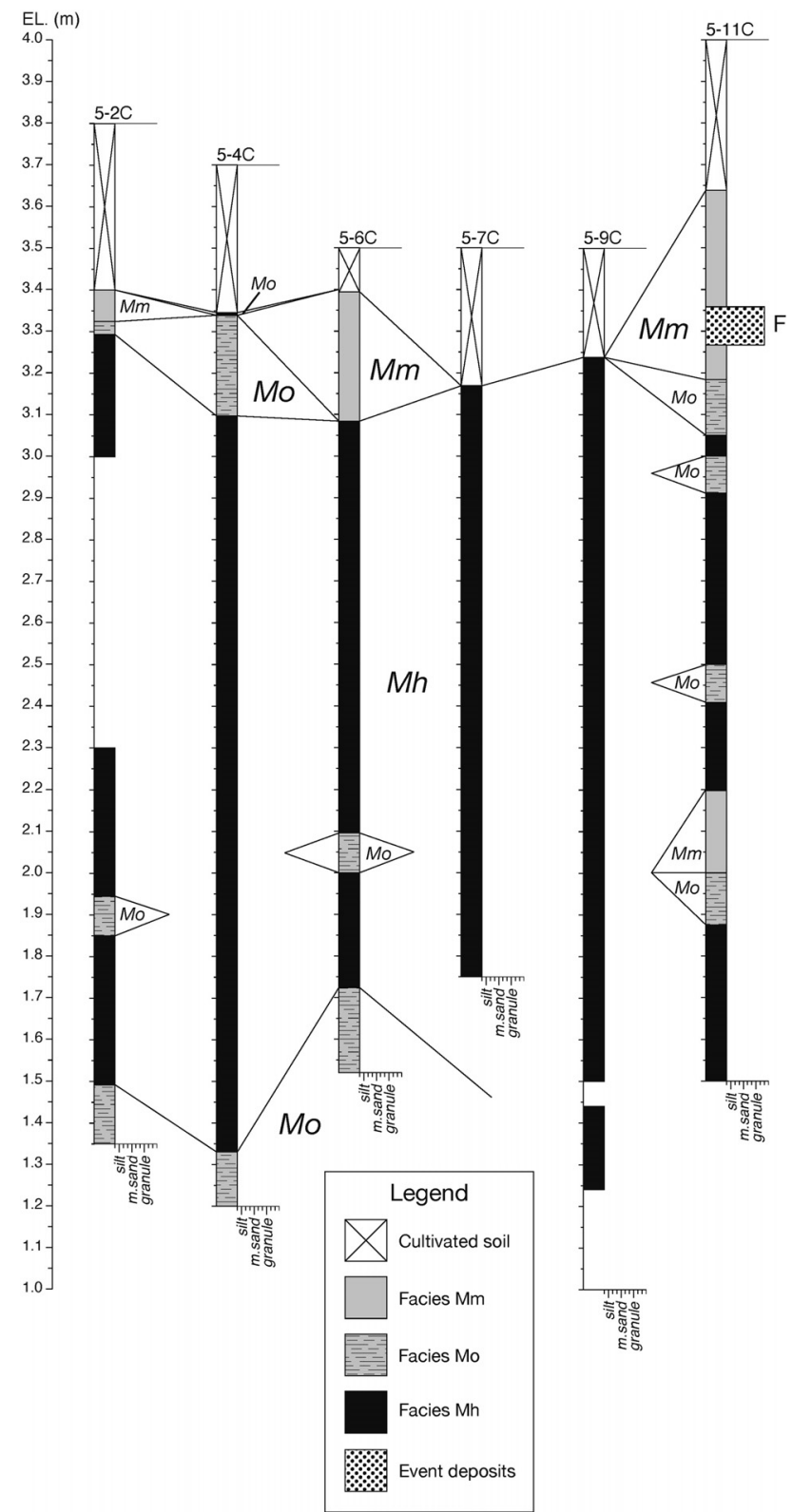

Fig. 5 Columnar sections of Line 3. F: The event deposit.

ら陸側に分布高度が下がる。陸側ではこれに代わって湿 地, あるいは池や沼の堆積物と解採される堆積相 $\mathrm{Mm}$, 堆 積相 Mo, 堆積相 Mh が分布する。 すなわち, 堆積相 Sm の 上面は, 調查地域のすぐ北にある浜堤の陸側斜面の延長で あり，この浜堤が海成段丘からなる丘陵との間に凹地を形 成した。 その後, この凹地が湿地や池になり, 埋積されて 現在の低地が作られた。堆積相 $\mathrm{Mm}$, 堆積相 Mo, 堆積相 $\mathrm{Mh}$ の不明瞭な上下関係は, 部分的な水深や水流の違いを 反映しているものと思われるが, 上方に向かって砕首粒子 


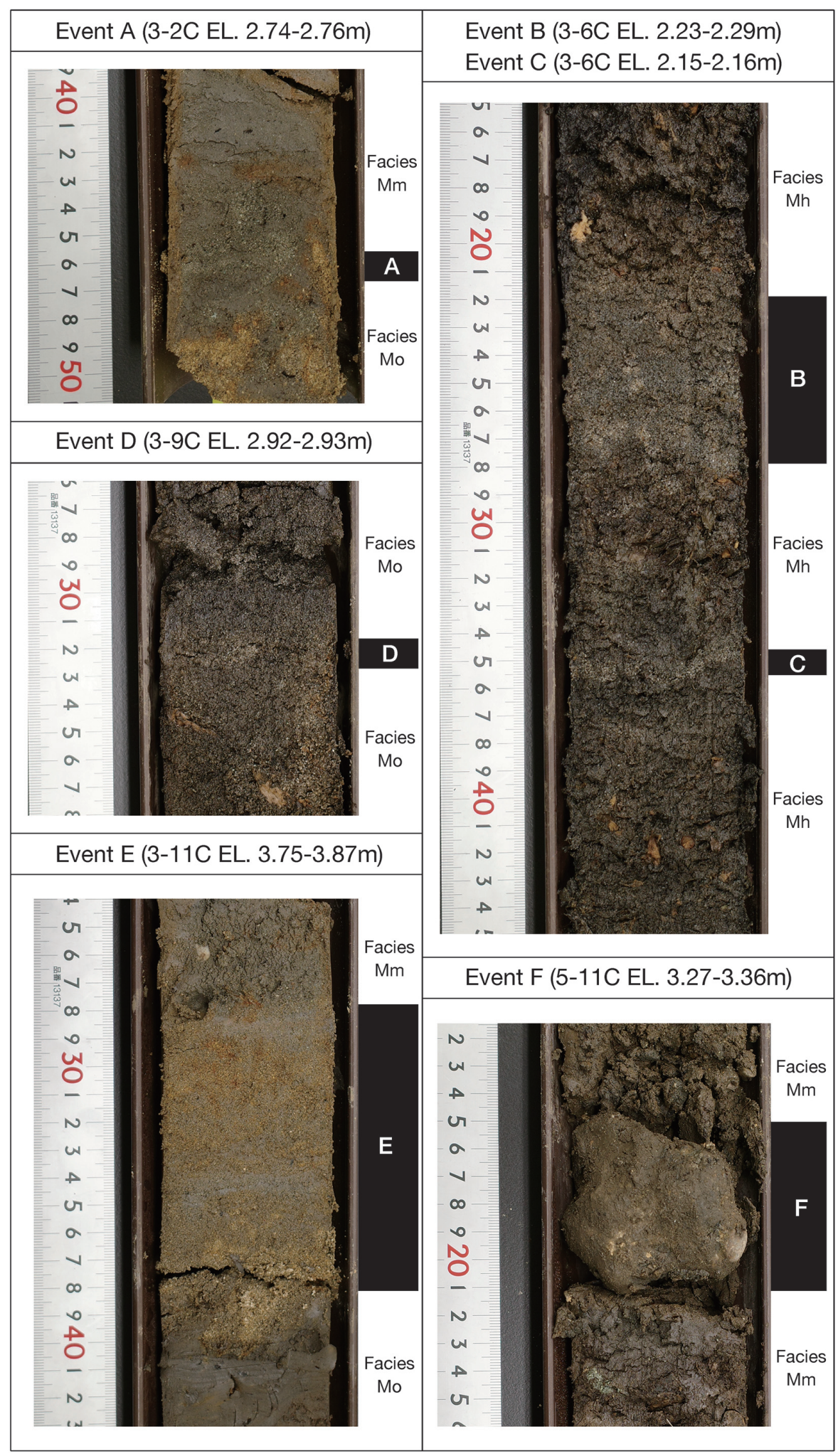

Fig. 6 Close up photos of the event deposits. 
Table 1 Results of the radiocarbon dating.

\begin{tabular}{cccccc}
\hline Sample & $\begin{array}{c}\text { Type of } \\
\text { Material }\end{array}$ & $\delta^{13} \mathrm{C}(\%)$ & ${ }^{14} \mathrm{C}$ Age (yr BP) & $\begin{array}{c}\text { Calibration Age (cal. yr BP) } \\
\text { / Probability (\%) }\end{array}$ & Labo No. \\
\hline \hline HMS3-2_01 & wood & -27.62 & $2250 \pm 30$ & $2270-2155 / 95.4$ & Beta-546872 \\
HMS3-2_02 & wood & -27.26 & $2520 \pm 30$ & $2643-2491 / 95.4$ & Beta-546873 \\
\hline
\end{tabular}

が増えることから, 徐々に水が流れ込むような環境になっ ていったことが示唆される.

\section{3. イベント堆積物の抽出とその特徵}

調査地域に分布する堆積物の中で, 浜堤背後の湿地の堆 積物は砕屑粒子に乏しく, 砂サイズ以上の粒子からなる層 は外的要因によるイベント堆積物とみなせる，そこで, 湿 地の堆積物中に挟まれる砂層をイベント堆積物として抽出 した. その結果, イベント層 $\mathrm{A} \sim \mathrm{F}$ の 6 層が抽出された (Fig. 6).

イベント層 A（地点 3-2C, 標高 2.74〜2.76 m) ; 黄色を呈 する淘汰の良い中粒砂〜細粒砂からなり，石英粒子を多く 含む. また，植物片を伴う，下位層との境界は明瞭で，わ ずかに逆級化する，上位層との境界は不明瞭で, 漸移的で ある. 層厚は $2 \mathrm{~cm}$ で, 堆積相 $\mathrm{Mo}$ と堆積相 $\mathrm{Mm}$ の間に挟 まれる。

イベント層 B（地点：3-6C, 標高 2.23〜2.29 m)；灰色〜 白色を呈する淘汰の良い中粒砂〜細粒砂からなり, 石英粒 子を多く含む. 明瞭な侵食基底が認められ, 正級化する. 上位層との境界は不明瞭で，漸移的である，層厚は $6 \mathrm{~cm}$ で, 堆積相 Mh 中に挟まれる。

イベント層 C（地点：3-6C, 標高 2.15〜2.16 m) ; 白色を 呈する淘汰の良い中粒砂からなり, 石英粒子を多く含む. 下位層, 上位層との境界は明瞭で, 堆積構造は認められな い. 層厚は $1 \mathrm{~cm}$ で, 堆積相 $\mathrm{Mh}$ 中に挟まれる.

イベント層 D（地点：3-9C，標高 2.92〜2.93 m)；白色を呈 する淘汰の良い中粒砂からなり，石英粒子を多く含む。下 位層, 上位層との境界は明暸で, 堆積構造は認められない. 層厚は $1 \mathrm{~cm}$ で, 堆積相 Mo 中に挟まれる.

イベント層 $\mathrm{E}$ (地点 : 3-11C, 標高 3.75 3.87 m) ; 黄土色 を呈する淘汰の良い細粒砂を主体とし，間に灰白色を呈す るシルトを挟む。明瞭な侵食基底と, 基底部に中粒砂が集 中する正級化構造, 平行葉理が認められる. 砂層は石英粒 子を多く含む．上位層との境界は明瞭である，層厚は 12 $\mathrm{cm}$ で, 堆積相 Mo と堆積相 Mm の間に挟まれる.

イベント層 $\mathrm{F}$ （地点：5-11C, 標高 $3.27 \sim 3.36 \mathrm{~m}$ ）; 直径 $12.1 \mathrm{~cm}$ の亜円碟. 堆積相 $\mathrm{Mm}$ の間に挟まれる.

\section{4. 放射性炭素年代測定結果}

放射性炭素年代測定の結果を Table 1 に示す. 試料名 HMS3-2_01 および試料名 HMS3-2_02 は, いずれも3-2C 地点のコアから採取した木片試料である. HMS3-2_01 は, イベント層Aの下位 $2.5 \mathrm{~cm}$ から採取した. HMS3-2_02 は, 深度 $1.250 \mathrm{~m}$ の堆積相 Mo と堆積相 Mh の境界から採取し た. 年代測定の結果, HMS3-2_01の年代は 2,344-2,155 cal BP であり, HMS3-2_02 の年代は 2,744-2,491 cal BP であっ た。

\section{考察}

\section{1. イベント層の対比}

本研究で抽出されたイベント層 $\mathrm{A} \sim \mathrm{F}$ は湿地の堆積物に 挟まれて分布する. 湿地は通常, 起伏の少ない低地に形成 されることから, 大規模なイベントの痕跡は側方にも分布 すると考えられる。この考えに基づけば，イベント層 A と イベント層 D はそれぞれ標高 $2.74 〜 2.76 \mathrm{~m}, 2.92 \sim 2.93 \mathrm{~m}$ と $\pm 20 \mathrm{~cm}$ の範囲に分布し, 対比される可能性がある（Fig. 4).この 2 層の側方に何らかのイベントの痕跡が残ってい れば, 対比される可能性がさらに高まると考え, そのよう な痕跡がないかを改めて確かめたところ, 複数のコアで標 高 $2.5 \sim 3.0 \mathrm{~m}$ の範囲に限って腐植の産状に変化が見られた (Fig. 7). 3-4Cでは, 標高 $2.80 \mathrm{~m}$ 付近に未分解の木の幹と 腐植の境界がある. 3-6C では, 標高 $2.75 \mathrm{~m}$ 付近を境に, 下 位では未分解の木片が含まれる。また，5-7C，5-9C，5$11 \mathrm{C}$ でも, 標高 2.5 3.0 m のコアに, 未分解の植物片が多 数含まれる層準がある. その他のコアでは, 腐植の産状に 明瞭な変化は認められなかった。 これらのことから, イベ ント層 $\mathrm{A}$ とイベント層 $\mathrm{D}$ は, 側方の植物片が濃集する層 準と合わせて，一連のイベントにより形成された可能性が 高い. なお, イベント層 $\mathrm{B}, \mathrm{C}, \mathrm{E}, \mathrm{F}$ は, 今回の調査では対 比されうる堆積物が見つからなかったため, その成因や規 模を推定することは難しいが，今後の調査の進展により， 議論が進むことが期待される. 




Fig. 7 Close up photos of the wood fragments rich layers. 


\section{2. イベント層 $\mathrm{A}$ とイベント層 $\mathrm{D}$ の成因}

イベント層 $\mathrm{A}$, イベント層 $\mathrm{D}$, および植物片の濃集層は, 平面的には海岸線と平行な方向に約 $700 \mathrm{~m}$, 海岸線に直交 する方向に約 $200 \mathrm{~m}$ の範囲に分布する。この範囲で砕首粒 子の運搬と植物片の濃集を同時にもたらすようなイベント として, 河川の汇濫，高潮，高波，そして津波が考えられ る.

イベント層 $\mathrm{A}$ やイベント層 D の下位には堆積相 $\mathrm{Sm}$ が 分布することから，調査地域のすぐ北にある浜堤は，これ らのイベント層の堆積時には既に存在していたと考えられ る. 当時のこの浜堤の幅や高さは不明であるが, 藤井・藤 （1982）によれば，イベント層 $\mathrm{A}$ が堆積した約 2,200 年前の 北陸地方の海水準は現在より $3 \mathrm{~m}$ ほど低かったとされてお り，調査地域まで高潮や高波が届いたとは考えにくい。イ ベント層 $\mathrm{A}$ とイベント層 $\mathrm{D}$ は, いずれも堆積相 $\mathrm{Sm}$ と同様 に石英粒子に富み，下位層との境界は明瞭で，一部で明暸 な侵食基底や正級化構造，逆級化構造が認められる。これ らの特徵は, 藤原（2004）や七山・重野（2004）が指摘した 津波堆積物の特徵と一致する。大型の植物片が濃集した層 は, 別の所で堆積した植物片が津波によって再移動したこ とや，近隣の地点において植生が破壊され，そこで生じた 植物片が移動・堆積したことで説明できる（例えば，菅野 ほか，2014）。これらのことから，ここで対比されたイベン 卜堆積物は津波により形成された可能性がある。一方，調 查地域周辺の約 $2.5 \mathrm{~km}$ 北西には仏生寺川があり (Fig. 1C), この川の氾濫によりイベント堆積物が形成された可能性も 否定できない. 今後, より広い範囲での調查や年代測定, イベント堆積物の微化石分析, 植物種の同定を行い, 成因 の特定を進める予定である.

\section{まと め}

富山県水見市島尾付近において, 浜堤の背後に広がる低 地で地層の堆積環境の変遷とイベント堆積物の連続性を確 認するため, 検土杖と打込み式サンプラーを用いて堆積物 の採取・記載と放射性炭素年代測定を行った，その結果， この低地の地層は浜堤の堆積物と, 浜堤背後の凹地を埋積 した湿地や池, 沼の堆積物からなることが分かった。この 浜堤背後の堆積物から, イベント堆積物が計 6 層検出され,
そのうち 2 層が対比される可能性があることが分かった。 2 層およびその側方の堆積物の特徵や, 調査地域周辺の地 形から, このイベント堆積物の成因は, 津波, あるいは河 川の氾濫の可能性がある。

謝辞 : 本研究を進めるにあたって, 島尾自治会長の嶋 敏 雄氏，ならびに島尾地区の皆様に多大なご協力をいただい た，応用地質株式会社の黑澤英樹氏，藤井正博博士，富山 大学理学部地球科学科（当時）の高橋秀徳氏, 小林素直氏, 相川 唯氏には, 現地調査にあたってご協力いただいた。 富山大学学術研究部の川㚡一雄博士には, 執筆にあたって ご協力いただいた，以上の方々に, 厚く御礼申し上げます。

\section{文献}

藤井昭二, 藤 則雄, 1982, 北陸における後水期以降の海水準変 動. 第四紀研究，21，183-193.

藤原 治, 2004, 津波堆積物の堆積学的・古生物学的特徴. 地質 学論集, 58, 35-44.

羽鳥德太郎，1984，北海道渡島沖津波（1741 年）の挙動の再検討 一1983 年日本海中部地震津波との比較一. 地震研究所彙報, 59, $115-125$.

羽鳥德太郎，1990，天保 4 年（1833 年）山形沖地震とその津波の 規模. 地震第 2 輯， 43，227-232.

国土庁土地局，1998，土地保全図（土地利用動向図 I）富山県, 国 土地図株式会社発行, 地図 1 葉.

七山 太, 重野聖之, 2004, 遡上津波堆積物概論一沿岸低地の津 波堆積物に関する研究レビューから得られた堆積学的認定 基準一. 地質学論集, 58, 19-33.

菅野 洋, 平吹喜彦, 杉山多喜子, 富田瑞樹, 原慶太郎, 2014, 巨大津波直後の海岸林に生じた多様な立地の植生の変化. 保全生態学研究，19, 201-220.

卜部厚志, 矢田俊文, 高清水康博, 片岡香子, 山本博文, 鎌滝孝 信, 酒井哲弥, 酒井英男, 竹内 章, 平川一臣, 2015, 3.2.1.2 津波堆積物の調查. 平成 26 年度「日本海地震 ・津波調查プ ロジェクト」成果報告書, 63-74.

山崎 司, 藤 則雄, 広岡公夫, 加藤道雄, 高山俊昭, 1983, 富 山県水見市十二町層（薮田層）の古地磁気層序に関する予察 的検討．金沢大学教養部論集自然科学篇， 20, 29-41.

矢野さ损り，竹内 章，2014，富山県射水市放生津潟に打ける底 生有孔虫を用いた津波堆積物の検出. 日本地質学会第 121 年学術大会講演要旨, R19-P-5, p. 566. 


\title{
富山県水見市における古津波堆積物調查
}

\author{
立石 良・河村綾太, 2020, 堆積学研究, Vol. 79, No. 1, 27-36
}

Tateishi, R. and Kawamura, A.: In search of paleotsunami deposits in Himi city, Toyama prefecture Jour. Sed. Soc. Japan, Vol. 79, No. 1, 27-36

北陸地方北部における古津波履歴を明らかにすることを目的として, 富山県水見市島尾地区の浜 堤背後の低地で津波堆積物調查を行った，ハンドコアラーを用いて採取したコアの堆積相解析の結 果, この低地の地層は浜堤の堆積物と, 浜堤背後の凹地を埋積した湿地や池, 沼の堆積物からなるこ とが分かった．この凹地の堆積物から，イベント堆積物が計 6 層抽出され，そのうち 2 層はほほ同 層準に分布すること，側方で植物片の濃集が観察されることから同一のイベントで堆積したものと 考えられる.このイベント堆積物は, その含有鉱物や堆積構造, 及び分布範囲の広さから, 津波に由 来する可能性がある，一方で，河川の汇濫による堆積物の可能性も残されており，成因を特定する ためには, 継続して調査を続ける必要がある。 なお, このイベント堆積物の直下の ${ }^{14} \mathrm{C}$ 年代は $2,344-$ 2,155 cal BP である. 